FEDERAL RESERVE BANK OF SAN FRANCISCO

WORKING PAPER SERIES

\title{
Reestablishing the Income-Democracy Nexus
}

\author{
Jess Benhabib \\ New York University \\ Alejandro Corvalan \\ New York University and \\ Universidad Diego Portales, Santiago de Chile \\ Mark M. Spiegel \\ Federal Reserve Bank of San Francisco
}

February 2011

Working Paper 2011-09

http://www.frbsf.org/publications/economics/papers/2011/wp11-09bk.pdf

The views in this paper are solely the responsibility of the authors and should not be interpreted as reflecting the views of the Federal Reserve Bank of San Francisco or the Board of Governors of the Federal Reserve System. 


\title{
REESTABLISHING THE INCOME-DEMOCRACY NEXUS
}

\author{
Jess Benhabib, \\ Alejandro Corvalan, \\ and \\ Mark M. Spiegel \\ ABSTRACT
}

\begin{abstract}
A number of recent empirical studies have cast doubt on the "modernization theory" of democratization, which posits that increases in income are conducive to increases in democracy levels. This doubt stems mainly from the fact that while a strong positive correlation exists between income and democracy levels, the relationship disappears when one controls for country fixed effects. This raises the possibility that the correlation in the data reflects a third causal characteristic, such as institutional quality. In this paper, we reexamine the robustness of the income-democracy relationship. We extend the research on this topic in two dimensions: first, we make use of newer income data, which allows for the construction of larger samples with more within-country observations. Second, we concentrate on panel estimation methods that explicitly allow for the fact that the primary measures of democracy are censored with substantial mass at the boundaries, or binary censored variables. Our results show that when one uses both the new income data available and a properly non linear estimator, a statistically significant positive income-democracy relationship is robust to the inclusion of country fixed effects.
\end{abstract}

JEL Classification nos.: D72, E21

Keywords: income, democracy, modernization theory, censoring, dynamic panel

*Benhabib: New York University, $19 \mathrm{~W} .4^{\text {th }}$ Street, 6FL, New York, NY, 10012 (e-mail jess.benhabib@nyu.edu), Corvalan at NYU and Universidad Diego Portales, Santiago de Chile (email: alejandro.corvalan@nyu.edu), Spiegel: Federal Reserve Bank of San Francisco, Economic Research, 101 Market St., San Francisco, CA, 94105 (e-mail mark.spiegel@sf.frb.org). Israel Malkin provided excellent research assistance. We are grateful for comments from Stephane Bonhomme, William Easterly, Chris Flynn, Bryan Graham, Bo Honoré and Adam Przeworski. The views expressed are not necessarily those of the Federal Reserve Board of Governors or the Federal Reserve Bank of San Francisco. 


\section{Introduction}

The income-democracy correlation is the cornerstone of the "modernization theory". The theory claims a causal relation: democratic regimes are created and consolidated in affluent societies [e.g. Lipset (1959), Przeworski et al (1997), Barro (1999, Epstein et al (2006)]. Higher incomes reduce the intensity of conflict over the distribution of income, and thereby give way to democratic institutions that discourage expropriation and support redistributive fiscal policies under the rule of law [e.g.Benhabib and Rustichini (1996), Benhabib and Przeworski (2004)]. Alternatively, citizens of wealthier countries with high levels of human capital and high incomes may be more effective at creating and sustaining democratic institutions [e.g. Glaeser, et al (2004)]. Advocates of institutional explanations, however, view the causality in reverse: good democratic institutions that limit governments and protect property rights are conducive to economic growth [e.g. Acemoglu, et al (2001), Easterly and Levine (2003), Rodrik et al (2004)].

In well-known recent papers Acemoglu, et al [AJRY (2008), (2009)] cast doubt on the robustness of the cross-country empirical relationship between income and democracy. They demonstrate that the income-democracy relationship observed in the data is not robust to the inclusion of country fixed effects that capture various institutional differences across countries. ${ }^{1}$ Using Freedom House and Polity measures of democracy in a cross-country panel between 1960 and 2000, Acemoglu, et al conclude that with country fixed effects, the relationship between income and democracy disappears. They also obtain similar results for IV estimation. ${ }^{2}$ They extend their findings to a binary democracy measure used by Przeworski, et al (2000), and obtain similar results.

This paper re-establishes the correlation of income and democracy even after controlling for fixed effects. Our analysis confronts two primary issues: first, more and better-measured data on both income and democracy has become available since the publication of AJRY (2008). This development is crucial because the inclusion of country fixed effects reduces inference to that based on within-country variation

\footnotetext{
${ }^{1}$ For an earlier use of fixed effects in this context see Londregan and Poole (1997).

${ }^{2}$ AJRY (2008) instruments for income include lagged savings and weighted income changes of trading partners.
} 
in the data. However, as we show below, the initial Penn World Tables 6.1 (PWT 6.1) sample has data for shorter time spans than those available in either the newer Penn World Tables 6.3 data set [Heston, et al, (2009)] (PWT 6.3), or the alternative Maddison (2003) data set. As the small within-country sample may preclude a statistically-significant relationship between income and democracy, we use the larger PWT 6.3 and Maddison data sets to capture more of the variance of democracy in our estimations.

Second, the measures of democracy used in AJRY, based on Freedom House and Marshall Jaggers Polity IV (2004) samples are discrete and bounded, violating the maintained assumptions under OLS. We respond to this issue by using either a two-sided Tobit specification or the double-censoring specification of Alan, et al (2008). We also introduce a one-side censored measure of democracy - the Vanhanen Index of Democratization [Vanhanen (1990) and Vanhanen (2000)] -. Finally, we also examine a binary variable, such as that proposed by Alvarez, et al (1996) and Przeworski, et al (2000) henceforth called Democracy/Dictatorship (DD) - and use conditional and unconditional Logit specifications to obtain estimates. ${ }^{3}$ Additionally, for the four measures of democracy - Freedom House, Polity, Index of Democratization and DD - we also use the Wooldridge (2005) estimator (WE). This estimator generalizes the Chamberlain (1980) estimator used by AJRY (2009) and parameterizes the fixed effects as well as the initial conditions in a dynamic panel.

The remainder of this paper is divided into 5 sections. Section 2 introduces the data used in our study. Section 3 introduces our empirical methodology. Section 4 discusses our results. Section 5 conducts some robustness tests. Lastly, Section 6 concludes.

\section{Data}

\subsection{Measurement of income and democracy}

We consider a variety of income and democracy measures. First, to replicate the results in AJRY (2008), we use the same version of the Penn World Tables (6.1) [Heston et al (2002)] that they used. We

\footnotetext{
${ }^{3}$ See Corvalan (2010) for other nonlinear estimations with binary democracy
} 
then use the newer 2009 version of the Penn World Tables (6.3) that has greater coverage (189 countries vs 168 in PWT 6.1), and whose times series extend farther for most countries. ${ }^{4}$

We also use the Maddison Statistics on World Population, GDP and Per Capita GDP covering 202 countries [Maddison (2003)] ${ }^{5}$. We demonstrate that our Maddison data set tends to have greater coverage per country, facilitating the estimation of within-country variations. This allows us to evaluate the robustness of our results with the Penn World Tables data.

We next turn to the measurement of democracy. Much disagreement exists about the proper way to measure this variable (see Elkins (2000), Munk and Verkuilen (2002), Coppedge, et al (2008), and Cheibub, et al (2009) for recent discussions). A primary concern is whether democracy should be treated as a dichotomous, ordinal, or continuous variable. Bollen (1990) argues that the intensity of democracy is continuous by nature, and that a dichotomous index may result in a crude pooling of heterogeneous political regimes into a single categorization. Alternatively, Przeworski, et al (2000) reject the notion of a continuum, claiming that a country is either democratic or not.

We consider four alternative measures of the degree of democracy: First, we use the Freedom House Political Rights Index (FH), which allocates higher scores to countries that are closer to a set of characteristics that would be associated with a functioning democracy. Countries are coded with an integer scale between 1 and 7, corresponding to full democracy and autocracy respectively. This is the democracy variable favored in AJRY (2008). In the spirit of maximizing the availability of withincountry data, we follow Barro (1999) and AJRY (2008) in augmenting the index with the Bollen (2001)

\footnotetext{
${ }^{4}$ The earlier Penn World Tables have not been exempt from criticism. These criticisms point to the substantial degree of variability across different versions of the Penn World Tables [e.g. Johnson, et al (2009)] and to misgivings about purchasing power parity adjustments [Bergeijk (1998) and Johnson, et al (2009)]. In response, PWT 6.3 includes a new variable, RGDPL2 that should exhibit less variability across data revisions. In the interest of maximizing the comparability of our results with those in AJRY (2008), we report results for the RGDPCH variable below. However, we obtain almost identical results when using the RGDPL2 variable with the PWT 6.3 data set instead. This is unsurprising as the correlation between RGDPL2 and RGDPCH in our sample is 99\%. These results are available upon request.

${ }^{5}$ The number of countries reported is from the 2010 updated version of Maddison data set; see the homepage: http://www.ggdc.net/maddison/.
} 
data for 1950 - 1965, and also normalize the index to take values between 0 and $1 .^{6}$ This index ranks countries on that basis of a set of criteria, for example whether a country holds free and fair elections or not. $^{7}$

A notable feature of the FH index, which may be problematic for statistical inference, either with or without the inclusion of the Bollen data, is the substantial share of observations at either extreme, as shown in Figure 1. Almost 1/5 of the observations are coded as full democracies. This leaves the distribution of this variable bimodal. Moreover, a majority of these full democracies are high income countries which remain full democracies throughout our sample.

We also use the Marshall and Jaggers (2004) POLITY2 index (PI2). The POLITY2 index measures the difference between the Polity Democracy and Autocracy indices. It ranges from a score of 10 to 10, and represents a country's constraints on executive power through five indicators: (1) intensity of political competition, 2) regulation of political participation, (3) competitiveness of executive recruitment, (4) Openness of executive recruitment, and (5) the constraints it places on its chief executive. This variable is the same as the POLITY variable used in AJRY (2008) and AJRY (2009), with values included to account for periods "interruption", “interregnum”, and "transition". 8 It would be inappropriate to exclude these transition periods from the sample, as the inclusion of country fixed effects relies heavily on the transition periods for within-country variation in the data. As can be seen in Figure 1, the Polity2 data is also bimodal, with a substantial share of the countries in the sample designated as full democracies.

${ }^{6}$ The data is available for four years: 1950, 1955, 1960, and 1965. As in Barro (1999) and AJRY (2008), we use 1972 Freedom House figures for 1970.

${ }^{7}$ The FH index includes three questions about the electoral process, four questions on the extent of political pluralism and participation, and three questions on the functioning of government. For more details, see http://www.freedomhouse.org/template.cfm?page=35\&year=2006.

${ }^{8}$ The POLITY IV project manual [Marshall and Jaggers (2007)] indentifies interruptions as periods of foreign occupation or "short-lived" attempts at creating ethnic or religious federations, interregnums as periods of political authority collapse, and transitions as periods between to substantially different political regimes [Plümper and Neumayer (2010)]. For interruptions the POLITY II data set treats the data as missing as does POLITY; for interregnums, POLITY II assigns a neutral score while for transitions, POLITY II conducts linear interpolations between beginning and ending periods of the transition period. Effectively then, POLITY II differs from POLITY in distinguishing between interregnum and transition episodes and in smoothing changes along transition episodes. 
We also use Vanhanen's Index of Democratization [Vanhanen (1990) and (2000)]. This index is a composite measure of on voter participation rates and the intensity of election contestation, based on the share of votes captured by the opposition party (or parties). These measures are multiplied together to yield an overall index number. A country is considered a democracy if participation rates are at least $10 \%$, the share of the opposition party is at least $30 \%$, and the overall index number is sufficiently high. ${ }^{9}$ Unlike the FH and PI2 measures, the Vanhanen Index is not censored on the right hand side (see Figure 1). As such, the Vanhanen indices for wealthy democracies are still exhibiting gains in democracy: countries in Vanhanen Index increased their mean democracy from 9.7 to 16.5 from 1960 to 2000 while the subset of those countries which are democracies according to Polity2 index increased their mean from 26.1 to 33.0. Since the Vanhanen index is not censured on the right, the data is better able to track and indentify an income-democracy relationship, if one exists.

Finally, we consider a dichotomous index of democracy and dictatorship. We use the Democracy-Dictatorship (DD) measure introduced by Alvarez et al (1996) and extended by Cheibub et al (2010). This index gives a country a value of 1 at time t if it is considered a democracy and 0 otherwise. A regime is classified as a democracy if the following four conditions are all met: (1) the chief executive is chosen in a popular election, or by a popularly-elected legislature, (2) the legislature is popularly elected, (3) there is more than one political party competing in elections, and (4) an alternation in power under electoral rules identical to the ones that led to the incumbent taking power must have taken place.

We note that all democracy measures above are highly correlated, as the correlation coefficient between any pair of measures exceeds 0.8 (see Table 1).

\subsection{Resulting sample Panels}

\footnotetext{
${ }^{9}$ The overall index number is calculated as the share of participation times the share of the opposition party times 100, so that countries just meeting the minimum criteria in both categories would obtain an overall score of 3.0. The minimum threshold chosen for the overall index to indicate democracy is designated by Vanhanen (2000) as 5.0.
} 
Our base sample includes observations taken every fifth year from 1955 through $2000 .{ }^{10}$ We also examine 1 and 10 year panels over the same time period. ${ }^{11}$ As some countries received independence during this period, our base sample is unbalanced. 5 year intervals and the inclusion of lagged values are used to minimize serial correlation difficulties in the data as much as possible.

The differences between the panels for the five year data set using different measures of income and democracy are summarized in Table 2. We consistently obtain a larger sample when using the Penn World Tables 6.3 data set rather than the PWT 6.1 data set. For each of the three democracy measures we consider, the number of observations increases substantially, and number of observations per country does as well. We also observe an increase in the coefficient of variation for the democracy measure for all three democracy measures, although the percent of observations with changes in the democracy measure decreases modestly. In terms of country characteristics, the countries in our PWT 6.3 panels have higher per capita income and lower average democracy values for all three democracy measures.

Our panels using the Maddison data set are all also universally larger than their PWT 6.1 counterparts for any of our democracy measures. However, the relative sizes of the panels we obtain using the PWT 6.3 or Maddison data sets varies across democracy measures. The largest panel we obtain is that using the Maddison income data and the Polity2 democracy measure, with 2052 observations, almost double the amount we obtain with the Polity2 democracy measure and the PWT 6.1 income data. That panel also has the largest average number of observations within country, 13.07, which bodes well for our ability to identify the income democracy relationship in the presence of country fixed effects.

Overall, our use of alternative measures of income and democracy results in substantively larger samples, with increased within-country observations. Moreover, there is reason to believe that these new panels will be more informative, as the coefficient of variation in all of the democracy measures

\footnotetext{
${ }^{10}$ Reported results were robust to the inclusion of averages over five year periods instead. Five year periods are used to mitigate serial correlation problems.

${ }^{11}$ Following AJRY, our period of analysis is from 1960 to 2000. For the 5 year sample, the first lagged observation is from 1955. For the 10 year sample, however, the first lagged observation is from 1950.
} 
considered increases when one goes from the original PWT 6.1 data set to either the PWT 6.3 or Maddison alternatives.

\section{Estimation Methodology}

\subsection{Specification}

Consider the following specification

$$
d_{i t}=\alpha+\beta_{1} d_{i t-1}+\beta_{2} \log Y_{i t-1}+\delta_{t}+\theta_{i}+\varepsilon_{i t}
$$

where $d_{i t}$ and $\log Y_{i t-1}$ are democracy and log of GDP per capita for country i at period t respectively, $\delta_{t}$ and $\theta_{i}$ represent time and country fixed effects respectively, and $\varepsilon_{i t}$ is a disturbance term, assumed to be clustered by country.

The primary question stressed in the literature is the robustness of a statistically significant positive coefficient estimate for $\beta_{2}$ in the presence of the country fixed effects, $\theta_{i}$. There are strong reasons to believe that conditioning for cross-country differences is warranted. Country effects -- such as culture, religion, and the endowment of natural resources -- may indeed affect both democracy and income. As argued by AJRY (2008), this requires the inclusion of a fixed effects estimator that isolates within-country changes in the data.

However, the inclusion of fixed effects in equation (1), combined with the other variables, makes it difficult to establish the significance of income in the data. For our base specification below, the Rsquared is about 0.70 with only lagged democracy included. Introducing time and country dummies eliminates all common trends and cross-country correlations, further increasing the R-squared to $0.81 .^{12}$ The inclusion of all of these controls leaves little remaining variability to be explained, and therefore heightens the importance of considering the role of income in a data-rich panel.

\footnotetext{
${ }^{12}$ Results are for five-year panels 1955-2000 using FH democracy and PWT 6.3 income data.
} 
The linear specification (1) above however would not be suitable in the presence of our censored democracy measures especially since a substantial share of our sample falls on the boundaries. ${ }^{13}$ For this reason we move to non-linear Tobit and Logit estimations, as well as nonlinear dynamic panel methods that account for the inclusion of lagged democracy in our specification. ${ }^{14}$

\subsection{Estimation}

To take into account the non-linearities inherent in censored variables, we first turn to tobit estimation. However, even under a tobit specification our estimates may be inconsistent because of the incidental parameter problem. Because the specification is non-linear, fixed effects cannot be omitted through differencing and must be estimated from the same sample. As a result, an increase in the number of countries in our sample necessitates the estimation of these new parameters. This is inconsistent for a given length of within-country time series, and in turn can bias the other parameter estimates. Alan, et al (2008) provide moment conditions for a two-sided censored panel in the presence of fixed effects. We therefore also report the results of this approach using their estimator, termed “Two-sided” below.

Another source of concern is that our sample is a dynamic panel which includes lagged values of democracy. For the linear case, this problem can be treated with panel-GMM, such as the Arellano and Bond (1991) method used by AJRY (2008). ${ }^{15}$ However, our nonlinear specification presents a more challenging problem, as we cannot use differencing to eliminate the impact of country fixed effects. Taking the initial condition of the dependent variable as independent of unobserved heterogeneity will

\footnotetext{
${ }^{13}$ For binary variables a linear probability model would yield consistent estimates provided estimated probability coefficients are in $[0,1]$ but otherwise a nonlinear correction for estimates outside this interval would also be required.

${ }^{14}$ The use of non linear estimation methods for democracy is not new: see Przeworski et al (2000) for the use of Probit with DD and Epstein et al (2006) for the use of a Tobit estimator with POLITY2 data. Also Barro (1999) suggests that the use of non linear estimation would improve his approach.

${ }^{15}$ Bobba and Coviello (2007) and Castelló-Climent (2008) also conduct system-GMM estimates of censored democracy variables, finding a significant positive relationship between education and democracy.
} 
bias estimates in dynamic panels that are short in the time dimension. A number of authors have addressed this problem with various methods, including Heckman and MacCurdy (1980), Heckman (1981), Honoré (1993), Honoré and Kyriazidou (2000), and Wooldridge (2005). In this paper, we follow Wooldridge (2005), assuming that country fixed effects can be specified as a linear function of the mean sample value of the observable independent variables, the initial condition for the lagged dependent variables and country specific random effects. ${ }^{16}$ This approach is a generalization of the Chamberlain (1980) methodology used by AJRY (2008). ${ }^{17}$

For our dichotomous democracy measure, we use unconditional and conditional logit estimation. Both of these methodologies have strengths and weaknesses. Unconditional logit allows for the estimation of probabilities, but is not a T-consistent estimator, due to the incidental parameters problem. ${ }^{18}$ Conditional logit addresses this problem, but restricts us to investigating the statistical significance of the independent variables. We deal with dynamic panel issues for the dichotomous measure by again using the Wooldridge (2005) method described above.

\section{Results}

\subsection{Censored democracy measures}

The results using the FH measure of democracy are shown in Table 3. First, we demonstrate that our results are consistent with those in AJRY (2008) for OLS estimation. With country fixed effects excluded, we obtain positive and statistically significant coefficient estimates for lagged income values.

\footnotetext{
${ }^{16}$ One potential difficulty with this approach is that some of the initial conditions for the lagged dependent variables may lie on the boundary of the interval to which they are restricted, in turn restricting the range of the country specific fixed effects.

${ }^{17}$ As a robustness check, we also use the Chamberlain (1980) methodology with similar results.

${ }^{18}$ Corvalan (2010) provides a first-order correction for the incidental parameter bias that arises in estimation using an adjustment from Hanh and Kuersteiner (2004) and Fernandez-Val (2009). His estimates are very similar to those reported below.
} 
This is true for all three income measure samples. However, with fixed effects included, these results disappear, as all coefficient estimates are now smaller and statistically insignificant. We therefore verify that under OLS, the significance of lagged income on democracy levels is not robust to the inclusion of country fixed effects. We therefore switch to tobit and Two-Sided Estimators for censored data (see Alan et al (2008)).

Our results using either the tobit or the Two-Sided Estimator are still insignificant when we estimate income using the PWT 6.1 data set to measure income. However, we obtain quite different results for both the PWT 6.3 and Maddison income panels. For both specifications, coefficient estimates on income are larger, with income entering positive at least at a 5\% confidence level for both the PWT 6.3 and the Maddison panels using the TOBIT estimation method, and at a 5\% level for the Maddison data set using the Two-Sided Estimator method.

Note that the sample sizes are much increased using both alternative measures of income for all estimation methods. For this reason, we conclude that the relationship between income and democracy regains its statistical significance in the presence of country fixed effects when we use both the newer richer data sets and the nonlinear estimator appropriate for the censored measures of democracy.

In terms of the magnitude of the effects, consider that the mean value of lagged income in our sample is 8.36 for the PWT 6.3 data set and 7.83 for the Maddison data set, with standard deviations of 1.11 and 1.06 respectively. It follows that our point estimates indicate that a two standard deviation increase in lagged income would result in an increase of democracy of 0.16 for the PWT 6.3 sample and 0.22 for the Maddison samples. For example, beginning with the mean FH score of 0.51, a two standard deviation increase in lagged income would be predicted to increase the democracy score to 0.67 and 0.73 respectively. Such changes correspond to substantial increases in the level of democracy.

We now turn to our results with the Wooldridge estimator that also deals with the introduction of lagged democracy in our specifications. Lagged income is significant at a confidence level of $5 \%$ using 
both the PWT6.3 and Maddison data sets for income, with point estimates similar to the ones in the tobit and Two sided specifications.

We repeat the exercise using both the Polity2 and Vanhanen democracy measures. The results are shown in Table 4. These results are very similar to those we obtain with FH. For the Polity2 democracy measure and either income measure, lagged income enters positively and is statistically significant under OLS estimation when country fixed effects are excluded, but not when they are included. However, coefficient estimates under tobit and Two-Sided Estimators are statistically significant at least at a 10\% confidence level for both the PWT 6.3 and the Maddison income measures, with the Maddison panel coming in at 5\% significance under tobit. The magnitudes of our coefficient estimates are also similar to those that we obtained using the FH measure of democracy. For the Wooldridge estimator with Polity2 data, lagged income is significant at a confidence level of $1 \%$ using both the PWT6.3, and at 5\% level using Maddison data sets for income, again with point estimates comparable to those in our tobit and two sided specifications.

Next, we turn to the results with the Vanhanen democracy measure. In contrast to the democracy measures censored on both sides, the coefficient for lagged income, with fixed effects included, is now positive and significant at a $1 \%$ confidence level. With both the unconditional tobit and the Two-Sided Estimator the coefficient of lagged income is positive and significant at a 5\% confidence level for both measures of income. For the Wooldridge estimator with the Vanhanen measure of democracy lagged income is significant at a confidence level of $5 \%$ using both the PWT6.3, and at $1 \%$ level using the Maddison data set for income.

The OLS results with the Vanhannen measure differ from the OLS results for the other censored democracy measures: the significance of lagged income is robust to the inclusion of country fixed effects. This may be because the Vanhannen measure is censored only on the left, and is better able to capture the variability of democracy among countries with high measures of democracy. 


\subsection{Dichotomous measures of democracy}

The results for the dichotomous measures of democracy (DD) are shown in Table 5. The OLS results are repeated for completeness and are comparable to the results for dichotomous democracy measures obtained by AJRY (2009). Under a logit specification, lagged income enters positively at least a 5\% confidence level for all income measures under both conditional and unconditional logit estimation. The marginal effects for unconditional logit are 0.682 and 0.848 , with estimated standard errors of 0.304 and 0.250 for PWT6.3 and Maddison, respectively. The estimated coefficients indicate that the presence or absence of democracy is extremely sensitive to income: one standard deviation increase in measured income under the Maddison data set would move the democracy measure almost from 0 to 1.

For the Wooldridge estimator with the DD democracy measure, lagged income is significant at a confidence level of 5\% using both the PWT6.3 and Maddison data sets for income. In this case, marginal effects are reduced on average to 0.2, meaning that a two standard deviation increase in income would increase the probability of being a democracy by about 40 percent.

Note that except for the sample using the Wooldridge estimator, the samples for our unconditional and conditional logit specifications for dichotomous democracy measures are effectively much smaller. This is because the country fixed effects completely account for the dichotomous democracy measure for those countries whose values do not change. With few exceptions, affluent countries tend to be measured as democracies throughout our sample. On the other hand, the Wooldridge estimator proxies for fixed effects using a function generated from observable data. This explains why the coefficients for unconditional and conditional logit are much larger than those obtained with the Wooldridge estimator. 


\section{Robustness Checks}

\subsection{Alternative samples and frequencies}

Next we consider a number of alternative specifications and samples to evaluate the robustness of our results. We first repeat the results using 1-year data for all our measures of democracy: the FH, Polity2, Vanhanen and DD dichotomous measures, and the PWT 6.3 and Maddison measures of income. Following AJRY(2008) we include 5 lags of democracy and income in the RHS of (1), and we report the F-statistic for the join significance of the 5 lags. As the 1-year data the panel is large enough in the time dimension, we report only the non linear estimations: unconditional Tobit for the case of censored democracy and unconditional logit for the case of dichotomous measures.

We next consider longer time intervals, estimating our sample over 10 year windows. We report the same nonlinear estimations as in the 1-year case, but also the Wooldridge estimation that corrects for the effect of initial conditions.

Finally we remove from our original samples some particular subsets of countries that can be driving our results. First, it is plausible that the democratization occurring in the socialist countries during this period was exceptional, and therefore not suitable for pooling with the rest of our sample. ${ }^{19}$ Second, Oil Exporters' countries may also be exceptional since large Oil reserve has been found to be detrimental for the formation of democratic institutions (see Ross 2001). ${ }^{20}$ We therefore experiment with a sample that excludes Oil exporting countries.

Our results are reported in table 6. The qualitative annual results are quite similar to those we obtained with our five year samples. Our variables of interest, the 5 lags of income, are jointly significant at a 5\% confidence level using the FH and POLITY2 measures of democracy and the Maddison data, but

\footnotetext{
${ }^{19}$ The set of socialist countries are the countries defined as Marxist in 1982 by Lenski, see Bollen (1994) for a description.

${ }^{20}$ The set of oil exporters countries are the 10 countries with higher oil export to GDP ratio, according to Ross (2001). The number of ten countries was chosen arbitrarily, but results are robust to other numbers.
} 
is insignificant using the PWT6.3 data for FH and significant at 10\% for POLITY2. For the Vanhanen democracy index, significance is at $10 \%$ only for Maddison. Finally, for DD democracy measure, lagged income is significant at a $1 \%$ level for both measures of income. Overall, our lagged income is significant for 6 out of 8 specifications.

For 10-year time periods, lagged income is positive and significant at a $10 \%$ confidence level for 14 out of 16 specifications and significant at a 5\% level for 11 of the 16 specifications.

The results with socialist nations excluded are in general stronger than those that we obtain for our full sample. For all of our 12 specifications lagged income is positive and significant at least a $10 \%$ confidence level, and in 15 out of 16 at a 5\% confidence level or better. Once we exclude Oil exporters, lagged income is significant for all specifications except for the FH measure of democracy which is only significant for the Maddison income data. Overall, 14 out of 16 cases have significance at $10 \%$ and 10 cases at $5 \%$ or better.

\subsection{Additional covariates}

As emphasized by Lipset (1959), education is also considered an important aspect of modernization. An educated citizenry may constitute a pressure group for democracy and facilitate the functioning of democratic processes. To further investigate the role of education in fostering democracy as a competing explanation to income, we follow Barro (1999), Glaeser, et al (2004), and Acemoglu, et al (2005), by introducing lagged years of schooling as an explanatory variable. We also include a measure of population as a control, as in AJRY (2008). ${ }^{21}$

\footnotetext{
${ }^{21}$ AJRY (2008) also consider a group of variables termed "age structure," which consists of median age, as well as the share of the population of ages $0-15,15-30,30-45$, and $45-60$. Introducing these variables into our specification along with country fixed effects reduced the significance of income, which continued to enter at statistically significant levels using either the Vanhanen measure or DD measures, but not for the FH or POLITY2 measures.
} 
Our results are shown in Table 7. It can be seen that income almost universally continues to enter positively with education and population included, either together or separately, for all four of our

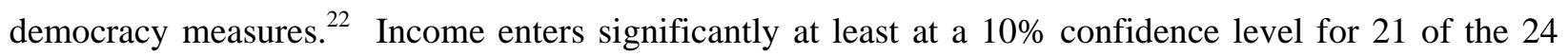
specifications we report. The coefficient estimates we obtain are also similar those we obtained above without including the covariates.

The performances of the covariates are not as strong. Average education in the population only enters significantly at least at the same $10 \%$ confidence level in only 4 of the 16 specifications in which it is included. For those specifications in which it does enter significantly, it takes its expected positive sign. Population does slightly better, entering significantly negative in 7 of the 16 specifications in which it is included. In all of these, it takes a negative sign, providing weak evidence that larger populations, holding all else equal, are less conducive to democratization. Overall, it appears that only income significantly predicts democracy levels once country fixed effects are included, beyond lagged levels of democracy itself.

\section{Conclusion}

The introduction of fixed effects sets a high bar for establishing that income is a significant explanatory variable for democracy in cross-country panel data. Our results suggest that the weak evidence for a causal empirical relationship between income and democracy found in the existing literature stemmed from two sources: A smaller, and perhaps less-accurately-measured panel of data for income, and the lack of the use of an appropriate estimator for the censored dependent measure of democracy. When we correct for both of these, we consistently find that lagged income is a positive and statistically significant variable in explaining democracy. There were some exceptions, but it appears that the bulk of the evidence favors of a statistical relationship between income and democratization.

\footnotetext{
${ }^{22}$ Results in Table 7 are reported for Maddison income measures. Results with PWT 6.3 income data are reported in appendix table A7.
} 
It should be stressed that both the larger sample sizes and the use of appropriate estimators were needed to regain a statistically significant relationship between income and democracy in the presence of fixed effects. As such, earlier studies were unable of finding this relationship with the older versions of the data. Only when the newer Penn World data, or the Maddison data, was combined with the proper non-linear estimators did the empirical relationship reappear in the presence of country fixed effects. Both of these corrections seem compelling; the dependent variables used in the study are indeed censored on both sides, with a substantial share of the data at the boundaries. Moreover, the creators of the Penn Tables themselves argue that the newer data set is superior, not just in terms of coverage, but also in the quality of measurement [Heston, et al (2009)]. 


\section{References}

Acemoglu, Daron, Simon Johnson, and James A. Robinson, (2001), "The Colonial Origins of Comparative Income and Democracy,” American Economic Review, 91(5), 1369-1401.

Acemoglu, Daron, Simon Johnson, James A. Robinson, and Pierre Yared, (2005), "From Education to Democracy,” American Economic Review, 95(2), 44-49.

Acemoglu, Daron, Simon Johnson, James A. Robinson, and Pierre Yared, (2008), "Income and Democracy,” American Economic Review, 98(3), 808-842.

Acemoglu, Daron, Simon Johnson, James A. Robinson, and Pierre Yared, (2009), "Reevaluating the Modernization Hypothesis,” Journal of Monetary Economics, 56, 1043-1058.

Alan, Sule, Bo E. Honoré, and Leth-Petersen, Sören,(2008), “Estimation of Panel Data Models with Twosided Censoring, mimeo, November 9.

Alvarez M, J.A.Cheibub, F.Limongi and A.Przeworski (1996), “Classifying Political Regimes”, Studies in Comparative International Development, 31(2): 3-36

Arellano, M., Bond, S.R., (1991) "Some specification tests for panel data: Monte Carlo evidence and an application to employment equations”, Review of Economic Studies 58, 277--298.

Barro, Robert, (1999), “Determinants of Democracy,” Journal of Political Economy, 107(6), 158-183.

Benhabib, J and Rustichini, R., (1996),"Social Conflict and Growth, "Journal of Economic Growth, 1, 125-142.

Benhabib, J., and Przeworski, A., (2006), "The Political Economy of Redistribution under Democracy," Economic Theory, 29, 271-290.

Bergeijk Peter A.G. van, (1998), "Did Real World Per Capita Income Really Grow Faster in 1870-1913 Than In 1973-1992?” De Economist 146(1): 143-159

Bobba M., and D. Coviello (2007), "Weak instruments and weak identification, in estimating the effects of education, on democracy”, Economic Letters 96, 301-306.

Boix, C. and S. Rosato, (2001), “A Complete Data Set of Political Regimes, 1800-1999,” mimeo, Department of Political Science, University of Chicago.

Bollen, Kenneth A., (1990), "Political Democracy: Conceptual and Measurement Traps," Studies in Comparative International Development,” 25, 7-24.

Bollen, Kenneth A. (1998), “Cross-National Indicators of Liberal Democracy, 1950-1990”, ICPSR 2532, University of North Carolina. 
Bollen, Kenneth A., (2001), “Cross-National Indicators of Liberal Democracy, 1950-1990.” $2^{\text {nd }}$ ICPSR version. Chapel Hill, NC: University of North Carolina, 1998. Inter-University Consortium for Political and Social Research.

Castelló-Climent, Amparo (2008), “On the Distribution of Education and Democracy,” Journal of Development Economics, 87, 179-190.

Chamberlain G. (1980), “Analysis of covariance with qualitative data”, Review of Economic Studies 47, pp. 225-238.

Cheibub, Jose A., Jennifer Gandhi, and James R. Vreeland, (2010), Democracy and Dictatorship Revisited,“ Public Choice, 143: 1-2, 67-101.

Coppedge, M., A. Alvarez, and C. Maldonado, (2008), "Two Persistent Dimensions of Democracy: Contestation and Inclusiveness,” Journal of Politics, 70(3), 632-647.

Corvalan, Alejandro, (2010), “The Effect of Income on Democracy During the Postwar,” mimeo.

Easterly W. and R. Levine (2003), “Tropics, Germs and Crops: How Endowments Influence Economic Development”, Journal of Monetary Economics 50(1): 3-39.

Elkins, Z., (2000), “Gradations of Democracy? Empirical Tests of Alternative Conceptualizations”, American Journal of Political Science, 44(2), 298-294.

Epstein, D., R. Bates, J. Goldstone, I. Kristensen and S. O’Halloran, (2006), “Democratic Transitions,” American Journal of Political Science, 50(3), 551-569.

Fernandez-Val, Ivan, (2009), "Fixed Effects Estimation of Structural Parameters and Marginal Effects in Panel Probit Models,” Journal of Econometrics, 150(1), 71-85.

Glaeser, Edward L.,Rafael La Porta, Florencio Lopez-de-Silanes, and Andrei Shleifer, (2004), "Do Institutions Cause Growth?,” Journal of Economic Growth, 9(3), 271-303.

Gronigen Growth and Development Centre (GGDC), (2010), "Explanatory Background Notes on Historical Statistics,” http://www.ggdc.net/MADDISON/oriindex.htm.

Hahn, Jinyong, and Guido Kuersteiner, (2004), “Bias Reduction for Dynamic Nonlinear Panel Models with Fixed Effects, mimeo, UCLA.

Heckman J.J. and T.E.MacCurdy (1980) “A Life Cycle Model of Female Labor Supply”, Review of Economic Studies 47: 47-74.

Heckman, J.J., (1981) "The incidental parameters problem and the problem of initial conditions in estimating a discrete time-discrete data stochastic process”, in: Manski, C.F., McFadden, D. (Eds.), Structural Analysis of Discrete Panel Data with Econometric Applications pp:179-195.

Heston, Alan, Robert Summers, and Bettina Aten, (2002), “Penn World Table Version 6.1," Center for International Comparisons of Production, Income, and Prices at the University of Pennsylvania 
Heston, Alan, Robert Summers, and Bettina Aten, (2009), “Penn World Table Version 6.3," Center for International Comparisons of Production, Income, and Prices at the University of Pennsylvania.

Honore Bo, (1993) "Orthogonality Conditions for Tobit Models with Fixed Effects and Lagged Dependent Variables”, Journal of Econometrics, 59: 35-61.

Honore B. and E.Kyriazidou (2000) "Panel Data Discrete Choice Models with Lagged Dependent Variable”, Econometrica 68(4): 839-874.

Johnson, Simon, William Larson, Chris Papageorgiou, Arvind Subramanian, (2009), "Is Newer Better? Penn World Table Revisions and Their Impact on Growth Estimates,” NBER Working Paper No. 15455, October.

Lipset, Seymour M., (1959), "Some Social Requisites of Democracy: Economic Development and Political Legitimacy,” American Political Science Review, 53(1), 69-105.

Londregan J.and K.T. Poole (1996) "Does High Income Promote Democracy?" World Politics, 49:1-30.

Maddison, Angus (2003), The World Economy: Historical Statistics, Paris: OECD

Marshall, Monty G. and Keith Jaggers, (2004), "Political Regime Characteristics and Transitions, 18002002.” College Park, MD: Polity IV Project, University of Maryland.

Marshall, Monty G. and Keith Jaggers, (2007), Polity IV project: Dataset User's Manual. George Mason University and Center for Systemic Peace.

Munk, G., and J. Verkuilen, (2002), “Conceptualizing and Measuring Democracy: Evaluating Alternative Indices,” Comparative Political Studies, 35(1): 5-34.

Plümper, Thomas, and Eric Neumayer, (2010), “The Level of Democracy during Interregnum Periods: Recoding the Polity2 Score,” Political Analysis, 18, 206-226.

Przeworski Adam and Fernando Limongi (1997), "Modernization: Theories and Facts”, World Politics 49:155-183.

Przeworski Adam, Michael Alvarez, José A. Cheibub and Fernando Limongi, (2000), Democracy and Development: Political Institutions and Material Well-being in the World, 1950-1990. New York: Cambridge University Press.

Rodrik D., A.Subramanian and F.Trebbi (2004), "Institutions Rule: The Primacy of Institutions over Geography and Integration in Economic Development” Journal of Economic Growth 9:131-165.

Ross Michael L., (2001) “Does Oil Hinder Democracy?”, World Politics 53(3): 325-361.

Vanhanen, Tatu, (1990), “The Process of Democratization,” New York: Crane Russak.

Vanhanen, Tatu, (2000), “A New Dataset for Measuring Democracy, 1810-1998.” Journal of Peace Research, 37(2), 251-265. 
Wooldridge Jeffrey M., (2005) "Simple Solutions to the Initial Conditions Problem in Dynamic, Non Linear Panel Data Models with Unobserved Heterogeneity”, Journal of Applied Econometrics 20: 39-54. 
Figure 1: Histogram of Measures of democracy: FH Bollen, Polity2, and Vahanen

\section{Measures of Democracy}

Histograms, Sample 1955-2000
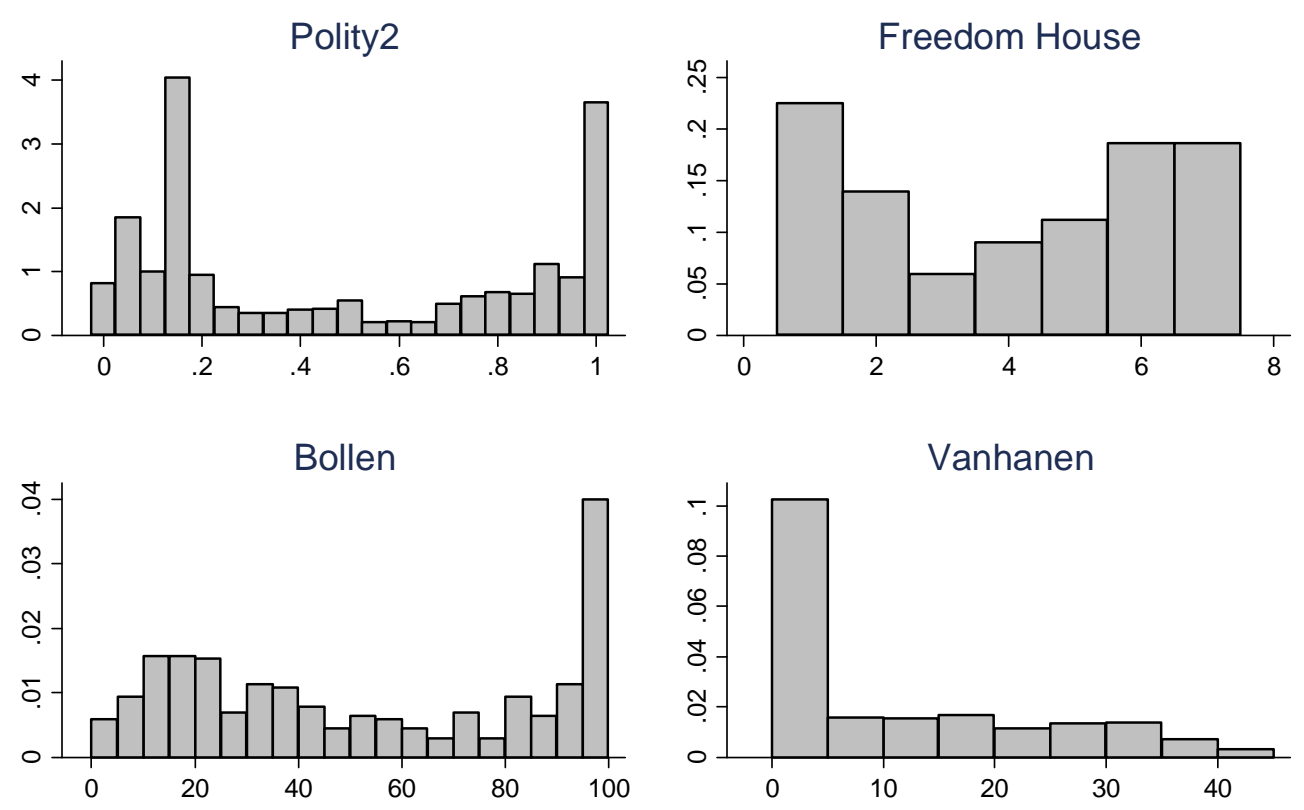

Note: Histograms for Polity2, Freedom House, Bollen and Vanhanen measures of democracy. Observations are for each 5 years from 1955 to 2000 for Polity2 and Vanhanen. For Freedom House, observations are from 1970 to 2000, and we use 1972 Freedom House figures for 1970. Bollen includes data for 1950, 1955, 1960, and 1965. 
TABLE 1: Correlations

\begin{tabular}{lcccc}
\hline & FH & PI2 & VAN & DD \\
\hline FH & 1 & & & \\
PI2 & 0.88 & 1 & & \\
VAN & 0.82 & 0.84 & 1 & \\
DD & 0.82 & 0.85 & 0.81 & 1 \\
\hline
\end{tabular}

Note: 1241 observations in the 5y sample

Note: Correlation coefficient estimates for four alternative democracy measures. 
Table 2. Summary Statistics

\begin{tabular}{|c|c|c|c|c|c|c|c|c|}
\hline $\begin{array}{c}\text { Democracy } \\
\text { Measure }\end{array}$ & $\begin{array}{c}\text { Income } \\
\text { Measure }\end{array}$ & $\begin{array}{c}\text { \# of } \\
\text { obs }\end{array}$ & $\begin{array}{c}\text { Observations } \\
\text { with change in } \\
\text { democracy } \\
\text { measure }\end{array}$ & $\begin{array}{c}\text { Observations } \\
\text { with democracy } \\
\text { measure not at } \\
\text { bounds }\end{array}$ & $\begin{array}{c}\text { Avg. \# of } \\
\text { observations } \\
\text { per country }\end{array}$ & $\begin{array}{c}\text { Avg. value } \\
\text { of } \\
\text { democracy } \\
\text { measure }\end{array}$ & $\begin{array}{c}\text { Coeff. Of } \\
\text { variation } \\
\text { for } \\
\text { democracy } \\
\text { measure }\end{array}$ & $\begin{array}{c}\text { Avg. per } \\
\text { capita } \\
\text { income }\end{array}$ \\
\hline \hline Freedom House & Penn 61 & 758 & $37 \%$ & $63 \%$ & 4.99 & 0.558 & 65 & 6709 \\
Freedom House & Penn 63 & 1151 & $36 \%$ & $61 \%$ & 6.26 & 0.525 & 71 & 9641 \\
Freedom House & Maddison & 1000 & $37 \%$ & $62 \%$ & 6.25 & 0.478 & 77 & 5562 \\
Polity2 & Penn 61 & 1054 & $31 \%$ & $77 \%$ & 7.64 & 0.564 & 66 & 5671 \\
Polity2 & Penn 63 & 1375 & $30 \%$ & $77 \%$ & 8.65 & 0.538 & 70 & 8075 \\
Polity2 & Maddison & 2052 & $29 \%$ & $78 \%$ & 13.07 & 0.517 & 70 & 4150 \\
Vanhanen & Penn 61 & 1129 & $29 \%$ & $71 \%$ & 7.37 & 0.285 & 102 & 5997 \\
Vanhanen & Penn 63 & 1360 & $34 \%$ & $66 \%$ & 7.43 & 0.255 & 111 & 8231 \\
Vanhanen & Maddison & 1902 & $35 \%$ & $65 \%$ & 11.96 & 0.189 & 136 \\
DD & Penn 61 & 1136 & $8 \%$ & - & 7.42 & 0.482 & 104 & 3893 \\
DD & Penn 63 & 1554 & $7 \%$ & - & 8.40 & 0.454 & 110 & 8496 \\
DD & Maddison & 1482 & $8 \%$ & - & 9.20 & 0.399 & 123 \\
\hline
\end{tabular}


TABLE 3: Results with Freedom House measure of democracy

\begin{tabular}{|c|c|c|c|c|c|c|c|c|c|c|c|c|c|c|c|}
\hline & \multicolumn{3}{|c|}{ OLS } & \multicolumn{3}{|c|}{ FE OLS } & \multicolumn{3}{|c|}{ Tobit } & \multicolumn{3}{|c|}{ Two sided } & \multicolumn{3}{|c|}{ Wooldridge } \\
\hline & penn 6.1 & penn 6.3 & maddison & penn 6.1 & penn 6.3 & maddison & penn 6.1 & penn 6.3 & maddison & penn 6.1 & penn 6.3 & maddison & penn 6.1 & penn 6.3 & maddison \\
\hline & \multicolumn{15}{|c|}{ Dependent variable is Freedom House Measure of Democracy } \\
\hline $\operatorname{dem}(t-1)$ & $\begin{array}{c}0.707^{* * *} \\
(0.04)\end{array}$ & $\begin{array}{c}0.802^{* * *} \\
(0.03)\end{array}$ & $\begin{array}{c}0.767^{* * *} \\
(0.03)\end{array}$ & $\begin{array}{c}0.383^{* * *} \\
(0.05)\end{array}$ & $\begin{array}{c}0.398^{* * *} \\
(0.05)\end{array}$ & $\begin{array}{c}0.428^{* * *} \\
(0.05)\end{array}$ & $\begin{array}{c}0.472^{* * *} \\
(0.06)\end{array}$ & $\begin{array}{c}0.497^{* * *} \\
(0.05)\end{array}$ & $\begin{array}{c}0.534^{* * *} \\
(0.06)\end{array}$ & $\begin{array}{c}0.469 * * * \\
(0.06)\end{array}$ & $\begin{array}{c}0.490^{* * *} \\
(0.05)\end{array}$ & $\begin{array}{c}0.514^{* * *} \\
(0.05)\end{array}$ & $\begin{array}{c}0.744^{* * *} \\
(0.05)\end{array}$ & $\begin{array}{c}0.773^{* * *} \\
(0.05)\end{array}$ & $\begin{array}{c}0.812^{* * *} \\
(0.05)\end{array}$ \\
\hline $\operatorname{inc}(\mathrm{t}-1)$ & $\begin{array}{c}0.072^{* * *} \\
(0.01)\end{array}$ & $\begin{array}{c}0.037^{* * *} \\
(0.01)\end{array}$ & $\begin{array}{c}0.055^{* * *} \\
(0.01)\end{array}$ & $\begin{array}{l}0.011 \\
(0.03)\end{array}$ & $\begin{array}{l}0.026 \\
(0.03)\end{array}$ & $\begin{array}{l}0.046 \\
(0.03)\end{array}$ & $\begin{array}{l}0.062 \\
(0.04)\end{array}$ & $\begin{array}{c}0.071^{* *} \\
(0.04)\end{array}$ & $\begin{array}{c}0.106^{* * *} \\
(0.04)\end{array}$ & $\begin{array}{r}0.033 \\
(0.04)\end{array}$ & $\begin{array}{l}0.047 \\
(0.03)\end{array}$ & $\begin{array}{c}0.075^{* *} \\
(0.04)\end{array}$ & $\begin{array}{r}0.053 \\
(0.04)\end{array}$ & $\begin{array}{c}0.066^{* *} \\
(0.03)\end{array}$ & $\begin{array}{c}0.076^{* *} \\
(0.03)\end{array}$ \\
\hline inc(mean) & & & & & & & & & & & & & $\begin{array}{c}0.087^{* *} \\
(0.04)\end{array}$ & $\begin{array}{l}0.014 \\
(0.03)\end{array}$ & $\begin{array}{c}0.03 \\
(0.04)\end{array}$ \\
\hline $\operatorname{dem}(0)$ & & & & & & & & & & & & & $\begin{array}{c}0.147^{* * *} \\
(0.05)\end{array}$ & $\begin{array}{c}0.319^{* * *} \\
(0.06)\end{array}$ & $\begin{array}{c}0.172^{* * *} \\
(0.05)\end{array}$ \\
\hline Observati & 947 & 1,129 & 1,070 & 947 & 1,129 & 1,070 & 947 & 1,129 & 1,070 & 947 & 1,129 & 1,070 & 947 & 1,129 & 1,070 \\
\hline R-squared & 0.726 & 0.731 & 0.73 & 0.796 & 0.808 & 0.797 & & & & & & & & & \\
\hline Left Censor & & & & & & & 109 & 171 & 187 & 109 & 171 & 187 & 109 & 171 & 187 \\
\hline Right Censo & & & & & & & 214 & 232 & 173 & 214 & 232 & 173 & 214 & 232 & 173 \\
\hline
\end{tabular}

Note: Estimation results using PWT 6.1, PWT 6.3, and Maddison income data as indicated, with Freedom House democracy measure. Estimation by ordinary least squares, with country fixed effects excluded and included, Tobit regression, Two-sided censored panel estimator, and Wooldridge dynamic panel estimator as indicated. See text for details. Standard errors in parentheses: errors are robust and clustered by countries for all estimations except Two sided. *** indicates statistical significance at $1 \%$ confidence level, ${ }^{* *}$ at $5 \%$ confidence level, and $* * *$ at $10 \%$ confidence level. Country and time fixed effect estimates suppressed, but available upon request. 
TABLE 4: Results with Polity 2 and Vanhanen measures of democracy

TABLE 4 - Results with Polity2 and Vanhanen Index

\begin{tabular}{|c|c|c|c|c|c|c|c|c|c|c|}
\hline & \multicolumn{2}{|c|}{ OLS } & \multicolumn{2}{|c|}{ FE OLS } & \multicolumn{2}{|c|}{ TOBIT } & \multicolumn{2}{|c|}{ Two Sides } & \multicolumn{2}{|c|}{ Wooldridge } \\
\hline & penn 6.3 & maddison & penn 6.3 & maddison & penn 6.3 & maddison & penn 6.3 & maddison & penn 6.3 & maddison \\
\hline PANELI & \multicolumn{10}{|c|}{ Dependent variable is Polity2 measure of democracy } \\
\hline $\operatorname{dem}(t-1)$ & $\begin{array}{c}0.813^{* * *} \\
(0.03)\end{array}$ & $\begin{array}{c}0.795^{* * *} \\
(0.03)\end{array}$ & $\begin{array}{c}0.438^{* * *} \\
(0.05)\end{array}$ & $\begin{array}{c}0.459^{* * *} \\
(0.05)\end{array}$ & $\begin{array}{c}0.424^{* * *} \\
(0.05)\end{array}$ & $\begin{array}{c}0.445^{* * *} \\
(0.05)\end{array}$ & $\begin{array}{c}0.476^{* * *} \\
(0.06)\end{array}$ & $\begin{array}{c}0.506^{* * *} \\
(0.06)\end{array}$ & $\begin{array}{c}0.566^{* * *} \\
(0.04)\end{array}$ & $\begin{array}{c}0.573^{* * *} \\
(0.04)\end{array}$ \\
\hline inc $(t-1)$ & $\begin{array}{c}0.026 * * * \\
(0.01)\end{array}$ & $\begin{array}{c}0.038 * * * \\
(0.01)\end{array}$ & $\begin{array}{c}0.015 \\
(0.03)\end{array}$ & $\begin{array}{c}0.017 \\
(0.03)\end{array}$ & $\begin{array}{c}0.054^{*} \\
(0.03)\end{array}$ & $\begin{array}{c}0.069 * * \\
(0.03)\end{array}$ & $\begin{array}{c}0.068 * \\
(0.04)\end{array}$ & $\begin{array}{c}0.078 * \\
(0.04)\end{array}$ & $\begin{array}{c}0.064^{* *} \\
(0.03)\end{array}$ & $\begin{array}{c}0.065^{* *} \\
(0.03)\end{array}$ \\
\hline inc(mean) & & & & & & & & & $\begin{array}{l}-0.005 \\
(0.03)\end{array}$ & $\begin{array}{c}0.028 \\
(0.03)\end{array}$ \\
\hline $\operatorname{dem}(0)$ & & & & & & & & & $\begin{array}{c}0.422^{* * *} \\
(0.05)\end{array}$ & $\begin{array}{c}0.358 * * * \\
(0.05)\end{array}$ \\
\hline Observation: & 1,015 & 1,067 & 1,015 & 1,067 & 1,015 & 1,067 & 1,015 & 1,067 & 1,015 & 1,067 \\
\hline R-squared & 0.76 & 0.763 & 0.824 & 0.822 & & & & & & \\
\hline Left_censoreo & & & & & 36 & 38 & 36 & 38 & 36 & 38 \\
\hline Right_censore & red & & & & 196 & 190 & 196 & 190 & 196 & 190 \\
\hline PANEL II & & & Dep & endent var & ble is Vanh & anen meas & of democr & acy & & \\
\hline $\operatorname{dem}(t-1)$ & $\begin{array}{c}0.846^{* * *} \\
(0.03)\end{array}$ & $\begin{array}{c}0.804^{* * *} \\
(0.03)\end{array}$ & $\begin{array}{c}0.330 * * * \\
(0.05)\end{array}$ & $\begin{array}{c}0.356^{* * *} \\
(0.05)\end{array}$ & $\begin{array}{c}0.306^{* * *} \\
(0.05)\end{array}$ & $\begin{array}{c}0.331^{* * *} \\
(0.06)\end{array}$ & $\begin{array}{c}0.302^{* * *} \\
(0.05)\end{array}$ & $\begin{array}{c}0.318^{* * *} \\
(0.05)\end{array}$ & $\begin{array}{c}0.526 * * * \\
(0.05)\end{array}$ & $\begin{array}{c}0.530 * * * \\
(0.05)\end{array}$ \\
\hline $\operatorname{inc}(t-1)$ & $\begin{array}{c}0.011^{* * *} \\
(0.00)\end{array}$ & $\begin{array}{c}0.017^{* * *} \\
(0.00)\end{array}$ & $\begin{array}{c}0.025^{* * *} \\
(0.01)\end{array}$ & $\begin{array}{c}0.026 * * * \\
(0.01)\end{array}$ & $\begin{array}{c}0.022^{* *} \\
(0.01)\end{array}$ & $\begin{array}{c}0.030 * * \\
(0.01)\end{array}$ & $\begin{array}{c}0.030 * * \\
(0.01)\end{array}$ & $\begin{array}{c}0.034 * * \\
(0.01)\end{array}$ & $\begin{array}{c}0.024 * * * \\
(0.01)\end{array}$ & $\begin{array}{c}0.031^{* * *} \\
(0.01)\end{array}$ \\
\hline inc(mean) & & & & & & & & & $\begin{array}{c}-0.009 \\
(0.01)\end{array}$ & $\begin{array}{c}0 \\
(0.01)\end{array}$ \\
\hline $\operatorname{dem}(0)$ & & & & & & & & & $\begin{array}{c}0.472^{* * *} \\
(0.06)\end{array}$ & $\begin{array}{c}0.375^{* * *} \\
(0.06)\end{array}$ \\
\hline Observation: & 1,127 & 1,082 & 1,127 & 1,082 & 1,127 & 1,082 & 1,127 & 1,082 & 1,127 & 1,079 \\
\hline R-squared & 0.807 & 0.804 & 0.871 & 0.861 & & & & & & \\
\hline Left_censored & & & & & 381 & 424 & 381 & 424 & 381 & 424 \\
\hline Right_censore & red & & & & 0 & 0 & 0 & 0 & 0 & 0 \\
\hline
\end{tabular}

Note: Estimation results using PWT 6.3, and Maddison income data with Polity2 and Vanhanen democracy measures, as indicated. Estimation by ordinary least squares, with country fixed effects excluded and included, Tobit regression, Two-sided censored panel estimator, and Wooldridge dynamic panel estimator as indicated. See text for details. Standard errors in parentheses: errors are robust and clustered by countries for all estimations except Two sided. *** indicates statistical significance at $1 \%$ confidence level, $* *$ at $5 \%$ confidence level, and $* * *$ at $10 \%$ confidence level. Country and time fixed effect estimates suppressed, but available upon request. 
TABLE 5: Results with Binary DD measure of democracy

\begin{tabular}{|c|c|c|c|c|c|c|c|c|c|c|}
\hline & \multicolumn{2}{|c|}{ OLS } & \multicolumn{2}{|c|}{ FE OLS } & \multicolumn{2}{|c|}{ Unc.Logit } & \multicolumn{2}{|c|}{ Cond.Logit } & \multicolumn{2}{|c|}{ Wooldridge } \\
\hline & penn 6.3 & maddison & penn 6.3 & maddison & penn 6.3 & maddison & penn 6.3 & maddison & penn 6.3 & maddison \\
\hline & \multicolumn{10}{|c|}{ Dependent variable is Dem/Dict measure of democracy } \\
\hline $\operatorname{dem}(t-1)$ & $\begin{array}{c}0.772^{* * *} \\
(0.03)\end{array}$ & $\begin{array}{c}0.734^{* * *} \\
(0.04)\end{array}$ & $\begin{array}{c}0.343^{* * *} \\
(0.06)\end{array}$ & $\begin{array}{c}0.381^{* * *} \\
(0.06)\end{array}$ & $\begin{array}{c}0.876^{* *} \\
(0.43)\end{array}$ & $\begin{array}{c}1.626^{* * *} \\
(0.46)\end{array}$ & $\begin{array}{c}0.719^{* *} \\
(0.34)\end{array}$ & $\begin{array}{c}1.329 * * * \\
(0.33)\end{array}$ & $\begin{array}{c}2.758^{* * *} \\
(0.42)\end{array}$ & $\begin{array}{c}3.139 * * * \\
(0.38)\end{array}$ \\
\hline inc $(t-1)$ & $\begin{array}{c}0.038 * * * \\
(0.01)\end{array}$ & $\begin{array}{c}0.061^{* * *} \\
(0.01)\end{array}$ & $\begin{array}{c}0.062 \\
(0.04)\end{array}$ & $\begin{array}{c}0.07 \\
(0.05)\end{array}$ & $\begin{array}{c}2.835^{* *} \\
(1.26)\end{array}$ & $\begin{array}{c}3.741^{* * *} \\
(1.11)\end{array}$ & $\begin{array}{c}2.155^{* * *} \\
(0.80)\end{array}$ & $\begin{array}{c}2.957^{* * *} \\
(0.78)\end{array}$ & $\begin{array}{c}1.516^{* * *} \\
(0.59)\end{array}$ & $\begin{array}{c}1.409 * * \\
(0.59)\end{array}$ \\
\hline inc(mean) & & & & & ' & & & & $\begin{array}{c}-0.883 \\
(0.61)\end{array}$ & $\begin{array}{r}-0.353 \\
(0.60)\end{array}$ \\
\hline $\operatorname{dem}(0)$ & & & & & & & & & $\begin{array}{c}4.291^{* * *} \\
(1.03)\end{array}$ & $\begin{array}{c}2.420 * * * \\
(0.70)\end{array}$ \\
\hline Observations & 1,142 & 1,093 & 1,142 & 1,093 & 431 & 466 & 431 & 466 & 1,142 & 1,093 \\
\hline R-squared & 0.683 & 0.662 & 0.772 & 0.747 & & & & & & \\
\hline
\end{tabular}

Note: Estimation results using PWT 6.3, and Maddison income data as indicated with binary Democracydictatorship measure. Estimation by ordinary least squares, with country fixed effects excluded and included, unconditional and conditional Logit estimation, and Wooldridge dynamic panel estimator as indicated. See text for details. Robust standard errors clustered by country in parentheses. *** indicates statistical significance at $1 \%$ confidence level, $* *$ at $5 \%$ confidence level, and $* * *$ at $10 \%$ confidence level. Country and time fixed effect estimates suppressed, but available upon request. 


\begin{tabular}{|c|c|c|c|c|c|c|c|c|c|c|c|c|c|}
\hline \multicolumn{14}{|c|}{ Table 6: Robustness tests } \\
\hline & & \multicolumn{3}{|c|}{ Freedom House } & \multicolumn{3}{|c|}{ Polity2 } & \multicolumn{3}{|c|}{ Vanhanen } & \multicolumn{3}{|c|}{ Dem/Dict } \\
\hline \multirow[t]{2}{*}{ est. } & inc. & coef. & s.e. & obs. & coef. & s.e. & obs. & coef. & s.e. & obs. & coef. & s.e. & obs. \\
\hline & & \multicolumn{12}{|c|}{ Sample is each 1 year $1960-2000$ with $t-5$ in 1955} \\
\hline $\mathrm{NL}$ & p63 & {$[0.2$} & & 3684 & {$[0.05$} & $6]^{*}$ & 4594 & {$[0.66$} & & 5101 & {$[0.002$} & $* * *$ & 1982 \\
\hline \multirow[t]{2}{*}{$\mathrm{NL}$} & mad & {$[0.03$} & 7]** & 3262 & {$[0.01$} & 3]** & 4892 & {$[0.07$} & 4]* & 4968 & {$[0.002$} & $* * *$ & 2137 \\
\hline & & \multicolumn{12}{|c|}{ Sample is each 10 year 1960-2000 with t-10 in 1950} \\
\hline $\mathrm{NL}$ & p63 & $0.102^{*}$ & $(0.06)$ & 545 & $0.099 *$ & $(0.05)$ & 497 & $0.039 * *$ & $(0.02)$ & 552 & $3.726^{* *}$ & $(1.52)$ & 189 \\
\hline $\mathrm{NL}$ & mad & $0.151^{* *}$ & $(0.07)$ & 535 & $0.116^{* *}$ & $(0.06)$ & 542 & $0.049 * *$ & $(0.02)$ & 551 & $4.665 * * *$ & $(1.61)$ & 221 \\
\hline WE & p63 & 0.0328 & $(0.06)$ & 545 & $0.153^{* * *}$ & $(0.05)$ & 497 & $0.0341^{* *}$ & $(0.01)$ & 552 & $1.387^{* *}$ & $(0.67)$ & 559 \\
\hline \multirow[t]{2}{*}{ WE } & mad & 0.0919 & $(0.06)$ & 535 & $0.0982^{* *}$ & $(0.05)$ & 542 & $0.0469 * * *$ & $(0.02)$ & 551 & $1.148^{*}$ & $(0.63)$ & 557 \\
\hline & & \multicolumn{12}{|c|}{ Sample is each 5 year $1960-2000$ without Socialist Countries } \\
\hline $\mathrm{NL}$ & p63 & $0.079 * *$ & $(0.04)$ & 1,053 & $0.055^{*}$ & $(0.03)$ & 944 & $0.021^{* *}$ & $(0.01)$ & 1,050 & $2.582^{* *}$ & (1.20) & 399 \\
\hline $\mathrm{NL}$ & mad & $0.111^{* * *}$ & $(0.04)$ & 956 & $0.077^{* *}$ & $(0.04)$ & 955 & $0.033^{* *}$ & $(0.01)$ & 964 & $3.289 * * *$ & (1.06) & 421 \\
\hline WE & p63 & $0.0720^{* *}$ & $(0.03)$ & 1,053 & $0.0634^{* *}$ & $(0.03)$ & 944 & $0.0237 * * *$ & $(0.01)$ & 1,050 & $1.504^{* *}$ & $(0.60)$ & 1,065 \\
\hline \multirow[t]{2}{*}{ WE } & $\mathrm{mad}$ & $0.0823 * *$ & $(0.03)$ & 956 & $0.0717^{* * *}$ & $(0.03)$ & 955 & $0.0331 * * *$ & $(0.01)$ & 964 & $1.389^{* *}$ & $(0.58)$ & 975 \\
\hline & & \multicolumn{12}{|c|}{ Sample is each 10 year $1960-2000$ without Oil Exporters Countries } \\
\hline $\mathrm{NL}$ & p63 & 0.044 & $(0.04)$ & 1,075 & $0.054^{*}$ & $(0.03)$ & 966 & $0.021^{* *}$ & $(0.01)$ & 1,075 & $2.354^{*}$ & $(1.32)$ & 423 \\
\hline $\mathrm{NL}$ & mad & $0.094^{* *}$ & $(0.04)$ & 1,016 & $0.069 * *$ & $(0.03)$ & 1,011 & $0.030^{* *}$ & $(0.01)$ & 1,026 & $3.754^{* * *}$ & $(1.15)$ & 458 \\
\hline WE & p63 & 0.048 & $(0.03)$ & 1,075 & $0.075^{* * *}$ & $(0.03)$ & 966 & $0.022 * *$ & $(0.01)$ & 1,075 & $1.232^{* *}$ & (0.59) & 1,088 \\
\hline WE & $\mathrm{mad}$ & $0.066^{*}$ & $(0.04)$ & 1,016 & $0.066^{* *}$ & $(0.03)$ & 1,011 & $0.031 * * *$ & $(0.01)$ & 1,026 & $1.157^{*}$ & $(0.61)$ & 1,038 \\
\hline
\end{tabular}

Notes:

Dependent variable is democracy, measured as specified in column headings. Reported coefficient estimates for lagged income.

Income measured by Maddison data set.

NL Estimators are Unconditional Tobit for Freedom House, Polity2 and Vanhanen; Unconditional Logit for Dem/Dict.

WE is Wooldridge dynamic panel estimator

Errors are clustered across countries.

1 year panel specification includes 5 lags on democracy and income. Reported figure is prob>F for the joint significance of the 5 lags on income.

Socialist countries are defined as Marxist in 1982 according to Lasker, from the Bollen 1994 data set.

Oil Exporters are defined as the 10 countries with high ratio of Oil Exportation to GDP, from Ross 2001.

Specification includes lagged democracy, as well as country and time fixed effects.

Coefficient estimates for these are suppressed, but available upon request.

Notes: dependent variable is democracy, measured as specified in column headings. Reported estimates for lagged income. NL estimators are Unconditional Tobit for Freedom House, Polity2 and Vanhanen; Unconditional Logit for DD. WE is Wooldridge estimator. Robust standard errors clustered across countries are in parenthesis. 1 year panel specification includes 5 lags on democracy and income; reported figure is prob $>\mathrm{F}$ for the joint significance of the 5 lags on income. Socialist countries are defined as Marxist in 1982 according to Lasker, from the Bollen data set. Oil Exporters are defines as the 10 countries with high ratio of Oil Exportation to GDP, from Ross 2001. Specification includes lagged democracy as well country and time fixed effects; coefficient estimates for these are suppressed but available upon request. 


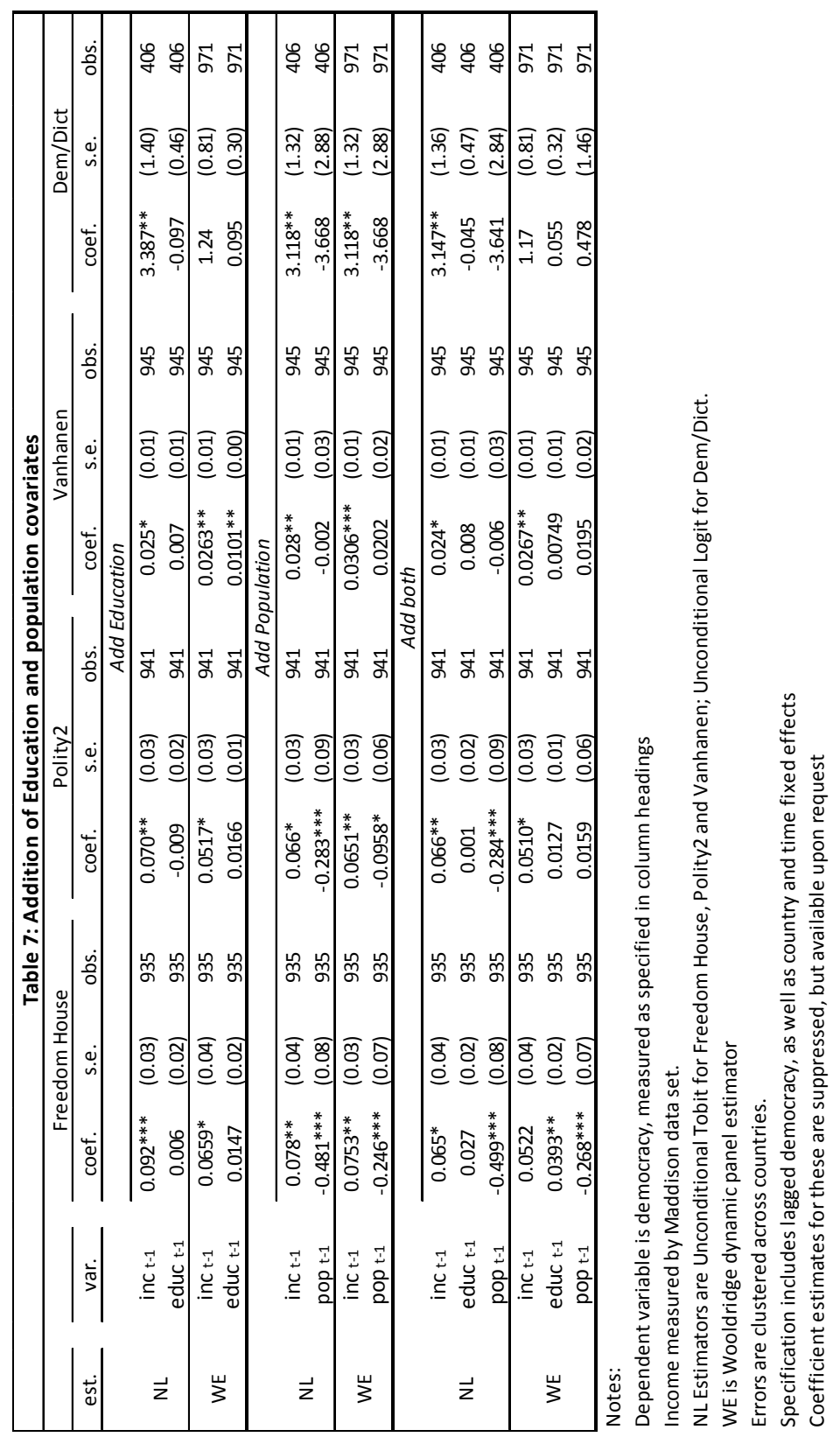




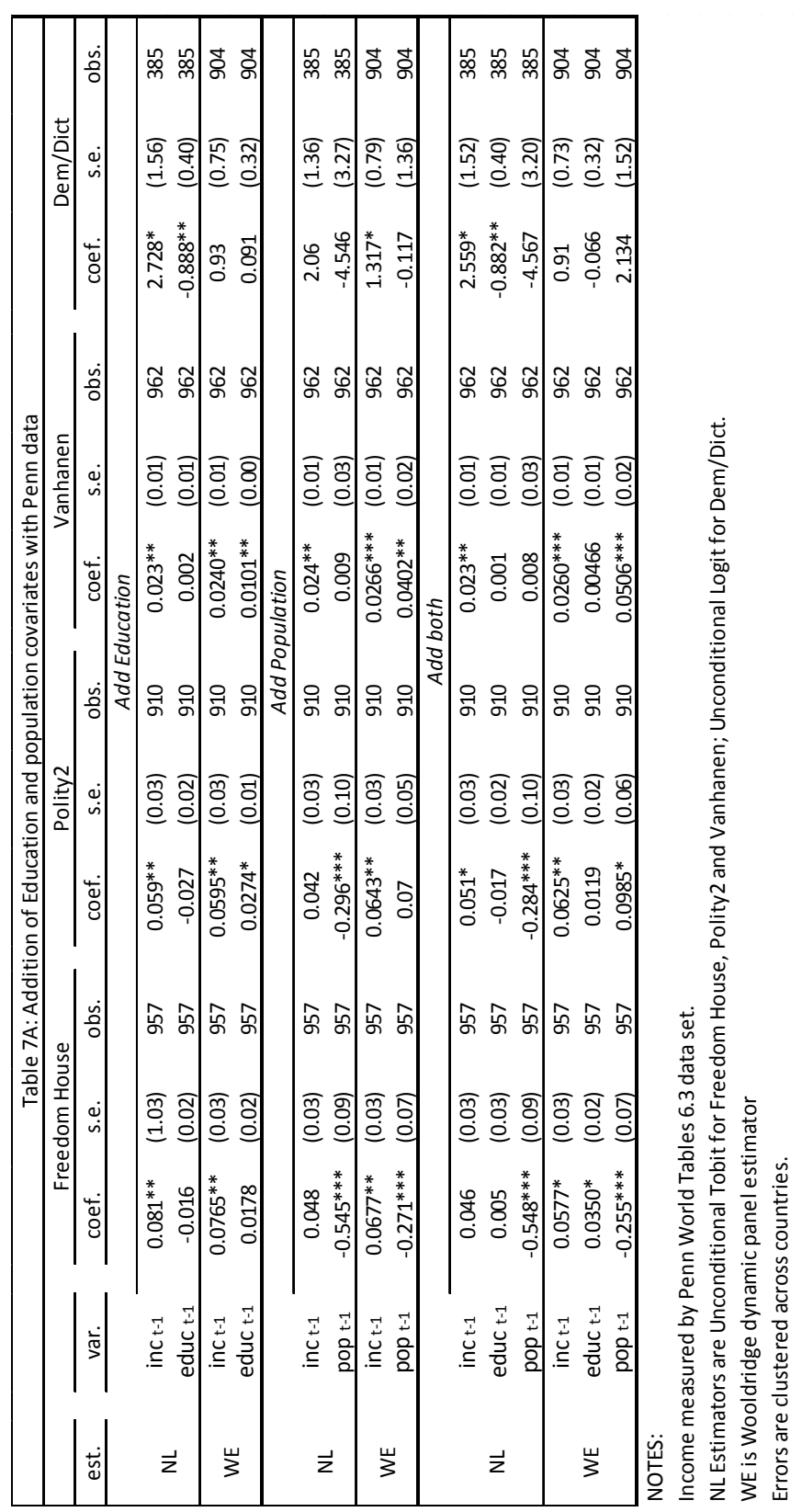

